\title{
Evidence in vivo for the two-cell hypothesis of oestrogen synthesis by the sheep Graafian follicle
}

\author{
D. T. Baird* \\ M.R.C. Reproductive Biology Unit, 2 Forrest Road, Edinburgh EH1 2QW, U.K.
}

After autotransplantation of different cell types to the anterior chamber of the eye in the rat, Falck (1959) proposed that granulosa and theca interna cells complemented one another in the synthesis of oestrogen by the Graafian follicle. Although numerous experiments in vitro support this 'two cell' hypothesis (Ryan, Petro \& Kaiser, 1968; Makris \& Ryan, 1975), most evidence suggests that in vivo oestrogen is synthesized exclusively by the theca cells (YoungLai \& Short, 1970; Channing \& Coudert, 1976). However, the report that FSH stimulates specifically the aromatization of androgens to oestrogens by ovaries in organ culture (Moon, Dorrington \& Armstrong, 1975), as well as by granulosa cells in tissue culture (Dorrington, Moon \& Armstrong, 1975), led us to re-examine the biosynthesis of oestrogens by the Graafian follicle in vivo. If androgens leave the thecal cell before aromatization, it should be possible to make them unavailable for the synthesis of oestrogen by antiandrogen antiserum.

Eight ewes with the left ovary autotransplanted to a carotid jugular skin loop in the neck (Goding, McCraken \& Baird, 1967) were used during January and February 1976. The experiments were performed in the follicular phase of the cycle $28 \mathrm{~h}$ after regression of the corpus luteum had been induced by an i.m. injection of $100 \mu \mathrm{g}$ ICI 80,996 , a potent luteolytic analogue of prostaglandin F-2 $\alpha$ (Baird \& Scaramuzzi, 1976). Oestrus occurred 24-48 h after the experiment, i.e. approximately 48-72 $\mathrm{h}$ after the injection of prostaglandin. On the morning of the experiment the ovarian artery and vein were cannulated via the left carotid artery and jugular vein respectively as previously described (Collett, Land \& Baird, 1973). After a rest period of $2 \mathrm{~h}$, timed samples of ovarian venous blood were collected at intervals of $10 \mathrm{~min}$ for $180 \mathrm{~min}$ (Text-fig. 1). Five minutes after each ovarian venous collection a sample of blood from the right jugular vein was collected for assay of LH. The blood was centrifuged immediately at $4^{\circ} \mathrm{C}$, a $5-\mathrm{ml}$ sample of plasma was aspirated under sterile conditions and kept for assay at $-20^{\circ} \mathrm{C}$, and the remaining plasma and red cells resuspended in $0.9 \%(\mathrm{w} / \mathrm{v})$ $\mathrm{NaCl}$ and transfused into the ewe (Baird, Swanston \& Scaramuzzi, 1976).

Oestradiol and $\mathrm{LH}$ were measured by radioimmunoassays, $\mathrm{LH}$ being expressed as ng equivalents of NIH-LH-S17 (Baird et al., 1976). The interassay coefficients of variation were 9.3 and $12.0 \%$ respectively.

In each experiment, antiserum was infused at the rate of $10 \mathrm{ml} / \mathrm{h}$ (about $1 / 70$ the total ovarian blood flow) into the ovarian artery by means of a Harvard Infusion Pump. Control antiserum, obtained from ewes immunized against bovine serum albumin (BSA), was infused into 8 ewes during the 1st and 3rd hours (Text-fig. 1, Table 1). In the 2nd hour, antiserum to testosterone (4 ewes) or oestrone ( 4 ewes) was infused. The specificity of the antisera was determined by measuring the dilution of antiserum which bound $50 \%$ of $5-10 \mathrm{pg}$ tritium-labelled steroid when incubated in vitro. The cross-reactions of the testosterone antiserum were $14 \%$ with androstenedione but $<2 \%$ with oestrone and oestradiol. The control antiserum and antiserum to oestrone had negligible crossreaction with androgens or oestradiol.

It has previously been reported that during the luteal phase of the oestrous cycle of the sheep, pulses of LH occur about every $2 \mathrm{~h}$ and are followed by a rapid increase in the secretion of oestradiol by the ovary (Baird et al., 1976). In the present experiments during the follicular phase the pulses of LH and oestradiol occurred more frequently (about once per hour (Text-fig. 1)). During the 2nd hour the titre of antiserum in ovarian venous plasma, defined as the $\%$ of 5-10 pg tritium-labelled steroid

* Present address: Department of Obstetrics and Gynaecology, University of Edinburgh, 23 Chalmers Street, Edinburgh, U.K. 


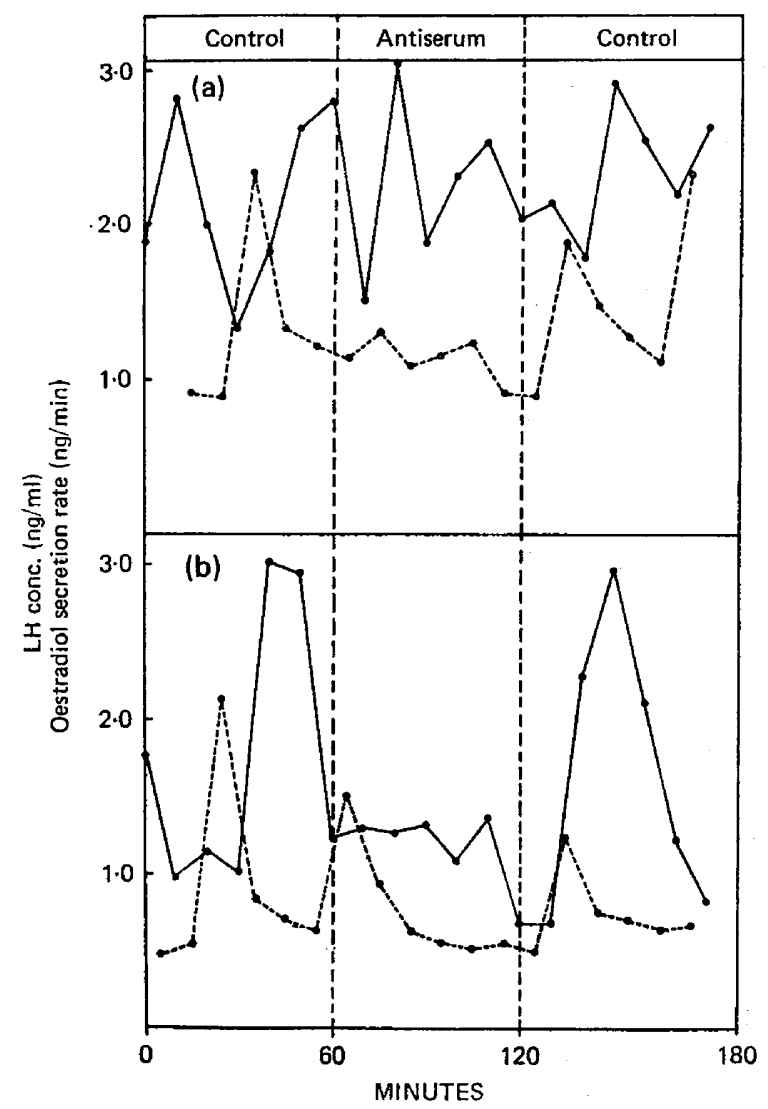

Text-fig. 1. Ovarian secretion of oestradiol (e) and the concentration of LH (O, ng equiv. NIH-LH-S-17) in the jugular vein in two ewes with ovarian autotransplants. Antiserum to bovine serum albumin (control) and either oestrone (a) or testosterone (b) was infused at the rate of $10 \mathrm{ml} / \mathrm{h}$ via the ovarian artery.

bound at a dilution of $1 / 100$, rose from non-specific levels ( $<3 \%$ ) to $61 \cdot 2 \pm 4 \cdot 2$ (S.E.M.) and $82 \cdot 4 \pm$ 4.7 for oestrone and testosterone respectively. During the infusion of antibodies to testosterone the secretion of oestradiol did not increase following an LH pulse (Text-fig. 1b) although it was maintained during infusion of the anti-oestrone serum. There was no difference in concentration of $\mathrm{LH}$ and secretion of oestradiol during infusion of control antiserum in the 1 st hour between the two groups.

Table 1. The secretion rate of oestradiol ( $\mathrm{ng} / \mathrm{min}$ ) during the infusion of antiserum through the ovarian artery of the ewe

\begin{tabular}{|c|c|c|c|c|c|}
\hline \multirow[b]{2}{*}{ Antiserum } & \multirow{2}{*}{$\begin{array}{l}\text { Control } \\
0-60 \text { min } \\
(28)\end{array}$} & \multicolumn{2}{|c|}{ Antiserum } & \multicolumn{2}{|c|}{ Control } \\
\hline & & $\begin{array}{l}60-90 \mathrm{~min} \\
\text { (12) }\end{array}$ & $\begin{array}{c}90-120 \mathrm{~min} \\
\text { (12) }\end{array}$ & $\begin{array}{c}120-150 \mathrm{~min} \\
(12)\end{array}$ & $\begin{array}{c}150-180 \mathrm{~min} \\
(12)\end{array}$ \\
\hline $\begin{array}{l}\text { Anti-oestrone } \\
\text { Anti-testosterone }\end{array}$ & $\begin{array}{l}2.21 \pm 0.35 \\
2.09 \pm 0.24\end{array}$ & $\begin{array}{l}2.46 \pm 0.58 \\
1.65 \pm 0.14\end{array}$ & $\begin{array}{r}3.10 \pm 0.56 \\
* * 0.95 \pm 0.08\end{array}$ & $\begin{array}{r}2.94 \pm 0.49 \\
* 1.12 \pm 0.21\end{array}$ & $\begin{array}{r}2.82 \pm 0.35 \\
* * 1.28 \pm 0.18\end{array}$ \\
\hline
\end{tabular}

Each figure is the mean \pm S.E.M. of 28 or $12(n)$ observations in 4 sheep. During the infusion of testosterone antiserum the secretion of oestradiol was significantly depressed when compared to the 1 st control period $(P<0.005)$ as well as to the corresponding value in the anti-oestrone experiments:

$* P<0.005 ;_{4}^{* *} P<0.001$. 
However, during and after the infusion of testosterone antiserum the secretion of oestradiol was significantly lower $(P<0.05$, Student's $t$ test $)$ when compared to the control hour or to the equivalent period of infusion of the oestrone antiserum (Table 1). The concentration of oestradiol in the oestrone antiserum $(0.75 \mathrm{ng} / \mathrm{ml})$ was higher than that of the testosterone antiserum $(0.18 \mathrm{ng} / \mathrm{ml}) \mathrm{but}$ the rate of infusion $(0.12 \mathrm{ng} / \mathrm{min})$ was not sufficient to account for the greater secretion in the ewes treated with oestrogen antiserum. There were no significant changes in the concentration of $\mathrm{LH}$ in ovarian or jugular venous plasma during the infusion although there was a tendency for the mean values to rise progressively throughout the experiment.

The sheep follicle releases both androstenedione and testosterone into the ovarian vein in vivo (Baird, Goding, Ichikawa \& McCracken, 1968) and into the medium when incubated in vitro (Seamark, Moor \& McIntosh, 1974). The fact that the secretion of oestradiol was depressed during the infusion of antibodies to testosterone suggests that these androgen precursors leave the ovarian cell (theca or granulosa) before aromatization in vivo. However, it is possible that a proportion of the oestrogen is synthesized from androgens produced locally within the cell because the secretion of oestrogen is not completely inhibited by the infusion of androgen antibodies and theca and granulosa cells can synthesize oestrogens in vitro (Ryan et al., 1968). It is suggested that androgens synthesized by the theca interna or stroma leave the cell and traverse the extracellular space and basement membrane before being converted to oestrogens by the granulosa cells under the influence of FSH (Dorrington et al., 1975). Androgen production by thecal and stromal cells has been implicated in the induction of follicular atresia (Louvet, Harman, Schreiber \& Ross, 1975). Only those follicles in which the granulosa cells have been activated by FSH can aromatize androgens and thus protect themselves from atresia.

I am grateful to $\mathrm{Mr}$ W. Davidson and Mr I Swanston for technical assistance and to Dr R. J. Scaramuzzi for the gift of antisera.

\section{References}

BaIRd, D.T. \& ScaramuzzI, R.J. (1975) Prostaglandin $F 2 \alpha$ luteal regression in the ewe: comparison with 16 , aryloxyprostaglandin (ICI 80,996). Annls Biol. anim. Biochim. Biophys. 15, 161-174.

BAIRD, D.T., GodING, J.R., ICHIKAWA, Y. \& MCCRACKEN, J.A. (1968) The secretion of steroids from the autotranspianted ovary in the ewe; spontaneously and in response to systemic gonadotrophins. $J$. Endocr. 42, 383-299.

Baird, D.T., Swanston, I. \& ScaramuzzI, R.J. (1976) Pulsatile release of $\mathrm{LH}$ and secretion of ovarian steroids in sheep during the luteal phase of the estrous cycle. Endocrinology 98, 1490-1496.

Channing, C.P. \& Coudert, S.P. (1976) Contribution of granulosa cells and follicular fluid to ovarian estrogen secretion in the rhesus monkey in vivo. Endocrinology 98, 590-597.

Collett, R.A., LAND, R.B. \& Baird, D.T. (1973) The pattern of progesterone secretion by the autotransplanted ovary of the ewe in response to ovine luteinizing hormone. J. Endocr. 56, 490-411.

Dorrington, J.H., Moon, Y.S. \& Armstrong, D.T. (1975) Estradiol-17 $\beta$ biosynthesis in cultured granulosa cells from hypophysectomized immature rats; stimulation by follicle-stimulating hormone. Endocrinology 97, 1328-1331.

FALCK, B. (1959) Site of production of oestrogen in rat ovary as studied in microtransplants. Acta physiol. scand. 47, Suppl. 163, 94-101.

Goding, J.R., MCCRACKen, J.A. \& BAIRd, D.T. (1967) The study of ovarian function in the ewe by means of a vascular autotransplantation technique. $J$. Endocr. $39,37-52$.

Louvet, J.P., Harman, S.M., Schreiber, J.R. \& Ross, G.T. (1975) Evidence for a role of androgens in foliicular maturation. Endocrinology 97, 366-370.

MAKRIS, A. \& RYAN, K.J. (1975) Progesterone, androstenedione, testosterone, estrone and estradiol synthesis in hamster ovarian follicle cells. Endocrinology 96, 694-701.

Moon, Y.S., Dorrington, J.H. \& Armstrong, D.T. (1975) Stimulatory action of follicle-stimulating hormone on estradiol-17 $\beta$ secretion by hypophysectomized rat ovaries in organ culture. Endocrinology 97, 244-247.

Ryan, K.J., Petro, Z. \& Kaiser, J. (1968) Steroid formation by isolated and recombined ovarian granulosa and thecal cells. J. clin. Endocr. Metab. 28, 355-358.

Seamark, R.F., Moor, R.M. \& MCINTOSH, J.E.A. (1974) Steroid hormone production by sheep ovarian follicles cultured in vitro. J. Reprod. Fert. 41, 143-158.

Younglai, E.V. \& ShorT, R.V. (1970) Pathways of steroid biosynthesis in the intact Graafian follicle of mares in oestrus. J. Endocr. 47, 321-331. 